\title{
In vitro plant regeneration of Christmas cactus (Schlumbergera truncata (Haw.) Moran) by indirect morphogenesis
}

\author{
Oksana Chornobrov ${ }^{1}$, Svitlana Bilous ${ }^{2,3} \bowtie$ \\ ${ }^{1}$ National University of Life and Environmental Sciences of Ukraine, Boyarka Forestry Research Station, \\ Plant Biotechnology Research Laboratory, Lisodoslidna 12, Boyarka 08150, Kyiv-Svyatoshyn distrist, Ukraine \\ ${ }^{2}$ National University of Life and Environmental Sciences of Ukraine, Botany, Dendrology and Forest Tree Breeding \\ Department, General Rodimtsev 19, Kyiv 03041, Ukraine, e-mail: forest_biotech@nubip.edu.ua \\ ${ }^{3}$ Institute for Evolutionary Ecology NAS Ukraine, Department of Dendrology and Park Learning, Lebedeva 37, Kyiv, \\ 03143, Ukraine
}

\begin{abstract}
Plants of Schlumbergera truncata (Haw.) Moran were obtained by indirect morphogenesis from the segment section of shoots in vitro, they were multiplied and rooted. Also were determined the effect of the lighting regime, the composition of the nutrient medium on the consistency and frequency of callus formation. The studies were conducted during 2016-2018. The mode of effective sterilization (more than 90\%) of $S$. truncata plant explants using $0.1 \%$ $\mathrm{HgCl}_{2}$ for 7-8 min was established. Optimal conditions for the induction of callus formation in stem node segments of $S$. truncata plants (rate more than $90 \%$ and significant growth) were created on MS (Murashige and Skoog 1962) nutrient medium supplemented with $1.0 \mathrm{mg} / 1$ BAP (6-benzylaminopurine) and $0.3 \mathrm{mg} / 1 \mathrm{NAA}$ (1-naphthylacetic acid) under conditions of placement on the nutrient medium and doing a significant number of cuts on the explants. The light intensity of 2.0-3.0 klx, obtained by a callus of dense consistency of dark green pigmentation, when using the thermostat condition without illumination, the callus had loose consistency, dark yellow pigmentation. It is established that the influence of the lighting regime and the composition of the nutrient medium on the frequency of callus formation is statistically significant. The largest number of shoots was obtained on the MS medium with the addition of $2.0 \mathrm{mg} / \mathrm{l}$ of BA. At the same times, shoot proliferation and root induction in such numbers were observed on MS culture medium with the addition of $0.5 \mathrm{mg} / 1 \mathrm{BA}$ and $0.5 \mathrm{mg} / 1$ kinetin (multiplication factor $-8.8 \pm 0.6$ per 60 -day cultivation cycle).
\end{abstract}

\section{KeY WORDS}

Christmas cactus, nutrient medium, explant, callus, shoot proliferation, microclonal propagation 


\section{INTRODUCTION}

Nowadays, the mass reproduction of ornamental plants using biotechnological methods holds a prominent place in the industrial floriculture in the leading countries of the world (Kushnir et al. 2005). This is due to a number of advantages of plants obtained in vitro compared to traditional methods: they are virus-free, genetically homogeneous and healthy. In addition, in vitro plant tissues are successfully used as a donor material to improve the existing varieties and to create new ones with specified quality parameters via cell and genetic engineering methods, multiplication of rare and endangered plants (George 1993; Sriskandarajah et al. 2007; Chornobrov et al. 2019).

Plants of Schlumbergera truncata (Haw.) Moran species is one of the main protected ground cultures; they have dangling articulated green shoots, the ends of which are covered with numerous sharp buds and bright "multilevel" flowers with a long bundle of slender stamens. Plants of the Schlumbergera Lem. genus belong to the epiphytic cactus, whose homeland is the rainforests of the Southeast Brazil. Currently, Denmark, Japan, the United Kingdom, Germany and the Netherlands are the main countries where ornamental cacti are grown. Traditionally, this culture is propagated by parts of shoots, but this method causes the spread of a number of diseases of bacterial and fungal nature (Udalov 1980). Therefore, the use of microclonal reproduction, which allows to obtain a sufficient number of healthy regenerant plants during the year, is now particularly relevant (Butenko 1964; Staba 1969; Kalinin 1980; Kushnir 2005; Smith 2012).

The authors investigated the regenerative capacity of Schlumbergera genus tissues in vitro, selected optimal conditions of cultivation, studied somatic embryogenesis, and have transferred the target genes into plant material using the Agrobacterium tumefaciens vector system (Amir 2001; Al-Ramamneh et al. 2006; Sriskandarajah et al. 2004, 2007; Deeksha Raj et al. 2020). In particular, Perez et al. (1999) cultured S. truncata explants in LS liquid nutrient medium (Linsmaier and Skoog 1965) with the addition of $10 \mathrm{mg} \cdot \mathrm{l}^{-1}$ $(2.2 \mathrm{mg} / \mathrm{l})$ of kinetin, but the plants had a relatively small reproductive rate, and significant contamination was registered (Perez et al. 1999). Sriskandarajah and Serek (2004) have developed an effective protocol for microclonal reproduction of economically important Schlumbergera cultivars from axillary buds in vitro on MS medium (Murashige and Skoog 1962) supplemented with $3.5 \mu \mathrm{M}(0.8 \mathrm{mg} / \mathrm{l}) \mathrm{BA}$ and $2.5 \mu \mathrm{M}(0.5 \mathrm{mg} / \mathrm{l})$ IBA (Sriskandarajah et al. 2004). Adventive shoots formation by direct morphogenesis was registered by the authors on solid MS medium with the addition of $27 \mu \mathrm{M}$ (6.1 mg/l) BA, $27 \mu \mathrm{M}(5.9 \mathrm{mg} / \mathrm{l}) \mathrm{TDZ}$, and $27 \mu \mathrm{M}$ $(5.9 \mathrm{mg} / \mathrm{l})$ zeatin (Sriskandarajah et al. 2004). Active callus proliferation in Schlumbergera was recorded on the medium based on MS salts, Staba vitamins (Staba 1969), $22.5 \mu \mathrm{M}(5.0 \mathrm{mg} / \mathrm{l}) \mathrm{TDZ}$ and $1.3 \mu \mathrm{M}(0.2 \mathrm{mg} / \mathrm{l})$ NAA. Subsequently, these calluses proliferated into somatic embryoids (Sriskandarajah et al. 2004; AlRamamneh et al. 2006).

Deeksha Raj et al. (2020) observed that direct regeneration was observed in MS media containing different concentrations of growth regulators BAP with constant $0.1 \mathrm{mg} / 1$ NAA. Early shoot proliferation was found in longitudinally sliced segment section and late response was found in transversely sliced segment section. The highest number of shoots was recorded in media containing $3 \mathrm{mg} / \mathrm{l}$ of BAP with constant $0.1 \mathrm{mg} / 1 \mathrm{NAA}$.

The regenerative capacity of tissues in vitro is affected by a number of factors (physiological, genetic, hormonal and physical), which determines the need for careful selection of cultivation conditions and nutrient media components for microclonal propagation of each Schlumbergera genotype individually.

In our previous publications, we have described the particular microclonal propagation of S. truncata by direct morphogenesis (Chornobrov and Bilous 2016). The next stage of the study was obtaining callus culture, induction of indirect morphogenesis, initiation of shoots growth, their proliferation and multiplication in vitro and mass production of plants.

The purpose of the study was to determine regeneration peculiarities of indirect morphogenesis of S. truncata from segment section for microclonal propagation.

\section{MATERIAL AND METHODS}

Phylloclade explant $\left(\mathrm{S}=0.5-0.8 \mathrm{~cm}^{2}\right)$ isolated from S. truncata 3-year-old donor plants in March were used for the studies. Sterilization of the plant material included the following operations: soaking in soap solution 
and running water (10-15 min), rinsing with distilled water (up to $1 \mathrm{~min}$ ), treatment with $70 \%$ ethyl alcohol (30-60 s), immersion into $0.1 \% \mathrm{HgCl}_{2}(7-8 \mathrm{~min})$ and 4-fold washing in sterile distilled water (10-15 min) (Chornobrov and Bilous 2016). At the stage of introduction into the culture in vitro, hormone-free nutrient medium according to the MS. Aseptic plant material was transferred to MS medium for 12-15 days with the addition of 2,4-dichlorophenoxyacetic acid (2.0 mg/1 2,4-D), 6-benzylaminopurine (1.0 mg / $1 \mathrm{BA}), 1$-naphthylacetic acid $(0.5 \mathrm{mg} / \mathrm{l} \mathrm{NAA})$. Each phylloclade was cut into 2-3 pieces and then artificially made notches with a scalpel. Obtaining in such a way, segments of sprouts were used as explants for callus formation. The callus formation frequency in explants were registered on day 25 of cultivation according to the conventional method (Butenko 1964; Kalinin et al. 1980).

Obtained sprouts from callus were transferred on MS medium supplemented with growth regulators: 3-indolyl butyric acid (1.0 mg/1 IBA), 6-benzylaminopurine $(0.5,2.0 \mathrm{mg} / \mathrm{l} \mathrm{BA})$ and 6-furfurylaminopurine $(0.25$, $0.5 \mathrm{mg} / \mathrm{l})$. kinetin). The medium was added $100 \mathrm{mg} / \mathrm{l}$ of myo-inositol, $30 \mathrm{~g} / \mathrm{l}$ of sucrose and 7.0-7.3 g/l of microbiological agar were added to the modified nutrient media. $2.0 \mathrm{~g} / 1$ of activated carbon was added to some variants of the nutrient medium. The acidity value of the medium $(\mathrm{pH})$ was brought to the level of 5.7-5.9. The growth characteristics of plant sprouts capable of regenerating were determined on day 60 of in vitro cultivation.

The plant material was cultured in a light room and a thermostat (without illumination) at $25 \pm 1^{\circ} \mathrm{C}$ and illumination $2.0-3.0 \mathrm{klx}$ with a 16 -hour photoperiod and a relative air humidity of $70-75 \%$. The hormone-free MS nutrient medium was used as a control. The studies were conducted over the period 2016-2018. The replication of experiments is 3-5 times. In the current study, the following biotechnological methods were used: plant tissue culture in vitro, microclonal reproduction and callus culture. MS Excel software package was used to process the experimental data, the mean and its standard error were calculated. To analyse the influence of the nutrient medium composition and the light regime on the frequency of callus formation, a two-way analysis of variance (ANOVA) with replication was performed. One-way analysis of variance was performed to analyse the influence of the nutrient composition on the micropropagation coefficient and the length of micro sprouts. In results, we used the following abbreviations: $\mathrm{F}$ - calculated $\mathrm{F}$ value, $\mathrm{F}_{1}$ - critical $\mathrm{F}$ value.

\section{Results}

To neutralize the exogenous microbiota of phylloclade explant of $S$. truncata plants, we used $0.1 \% \mathrm{HgCl}_{2}$ for 7-8 min (Chornobrov and Bilous 2016). This exposure mode allowed to obtain more than $90 \%$ of aseptic viable explants (Fig. 1a), which formed articulate sprouts on cultivation day 20-30 (Fig. 1a).

The intensity of dedifferentiation of S. truncata plant explants was highly dependent on the composition of the nutrient medium, in particular the concentration and the ratio of growth regulators of auxin and cytokinin modes of action, and cultivation conditions (Tab. 1).

Thus, the cultivation of explants under illumination conditions on a nutrient medium with the addition of $2.0 \mathrm{mg} / 1$ of 2,4-D tissues becomes thicker and swelling at the notch sites without subsequent callus formation.

The use of a similar nutrient medium under the conditions of cultivation of plant material in a thermostat without illumination caused a rather low activity of callus formation in their minor fraction.

A rather high rate of callus formation of explants (over $90 \%$ ), followed by significant tissue growth, was observed under the conditions of cultivation on solid MS medium with the addition of $1.0 \mathrm{mg} / \mathrm{l}$ of BA and $0.3 \mathrm{mg} / \mathrm{l}$ of NAA (Fig. 1b).

According to the results of analysis of variance (ANOVA), it was found that the effect of the interaction of the lighting regime and the composition of the nutrient medium on the callus formation frequency is statistically significant at $\alpha=0.05\left(\mathrm{~F}>\mathrm{F}_{1}, \mathrm{~F}=7.36, \mathrm{~F}_{1}=5.32\right.$, $\mathrm{p}<0.05$; where $\mathrm{F}$ - calculated $\mathrm{F}$ value, $\mathrm{F}_{1}-$ critical $\mathrm{F}$ value). There is a statistically significant difference between the frequency of callus formation on different nutrient media $\alpha=0.05\left(\mathrm{~F}>\mathrm{F}_{1}, \mathrm{~F}=184.09, \mathrm{~F}_{1}=5.32\right.$, $\mathrm{p}<0.05$ ). There was also a statistically significant difference between the frequency of callus formation at different light conditions at $\alpha=0.05\left(\mathrm{~F}>\mathrm{F}_{1}, \mathrm{~F}=11.00\right.$, $\left.\mathrm{F}_{1}=5.32, \mathrm{p}<0.05\right)($ Tab. 1).

The culturing conditions of the explants, in particular the illumination mode, determined the texture 
A

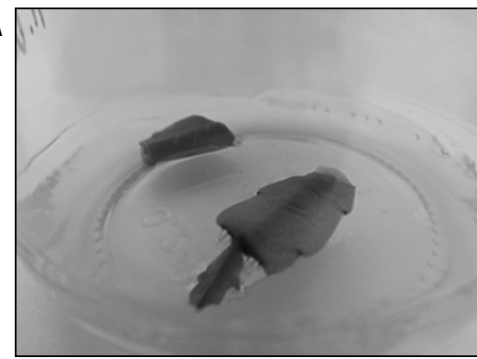

D

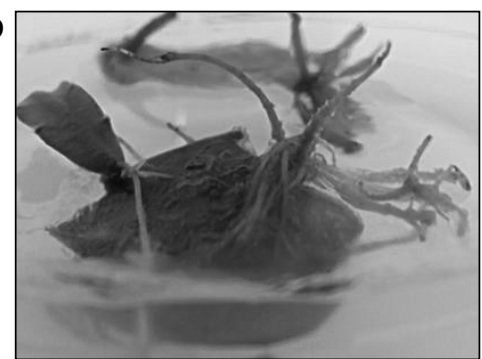

B

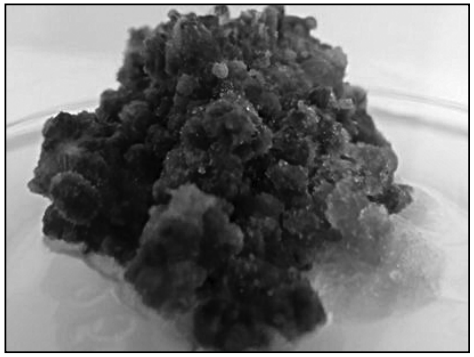

E

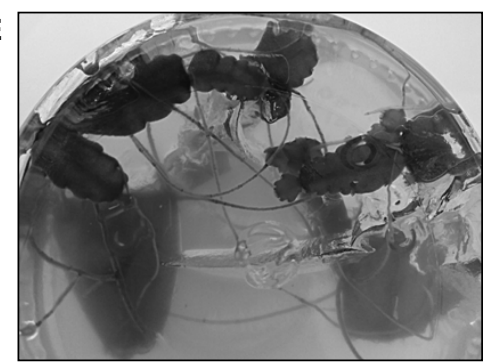

C

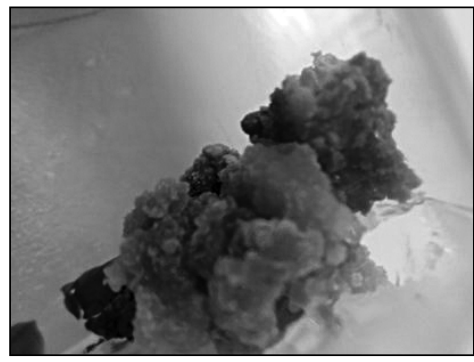

$\mathbf{F}$

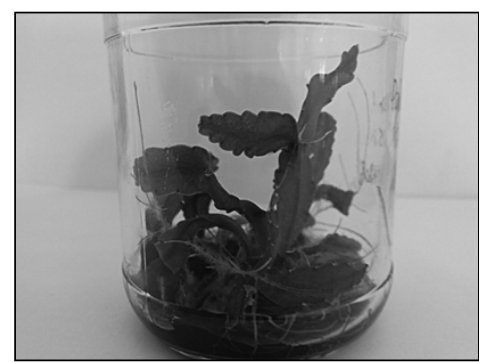

Figure 1. Plant regeneration Schlumbergera truncata (Haw.) Moran via indirect morphogenesis in vitro: A - aseptic viable culture and initiation formation of new cladode; B - morphogenic callus tissue on MS with $1.0 \mathrm{mg} / 1 \mathrm{BA}$ and 0.5 mg/1 NAA; $\mathrm{C}$ - friable callus culture; D, E - root system of plants at $1.0 \mathrm{mg} / 1 \mathrm{IBA} ; \mathrm{F}$ - rooted plant culture on modified MS

Table 1. The effect of growth regulators and conditions of illumination on the induction of callus formation in S. truncata plant explants, 25 days in in vitro culture

\begin{tabular}{|c|c|c|c|}
\hline \multirow[b]{2}{*}{ Variants } & \multirow[b]{2}{*}{$\begin{array}{l}\text { The composition } \\
\text { of the nutrient medium }\end{array}$} & \multicolumn{2}{|c|}{ Conditions of illumination } \\
\hline & & $\begin{array}{l}\text { Light room }(2.0-3.0 \mathrm{klx}) \\
\text { callus formation frequency } \\
\text { (mean } \pm \text { standard error), } \%\end{array}$ & $\begin{array}{l}\text { Thermostat (without light) } \\
\text { callus formation frequency } \\
\text { (mean } \pm \text { standard error), } \%\end{array}$ \\
\hline $\mathrm{C}$ & Control & 0 & 0 \\
\hline 1 & $\mathrm{MS}+2.0 \mathrm{mg} / 12.4-\mathrm{D}$ & 0 & $33.3 \pm 8.8$ \\
\hline 2 & $\mathrm{MS}+1.0 \mathrm{mg} / 1 \mathrm{BA}+0.5 \mathrm{mg} / \mathrm{l} \mathrm{NAA}$ & $90.0 \pm 5.8$ & $93.3 \pm 3.3$ \\
\hline
\end{tabular}

Notes: ${ }^{1} \mathrm{C}-$ control (hormone-free MS nutrient medium).

of the tissue. When the illumination with intensity of 2.0-3.0 klx was used, a callus of dense consistency, of dark green pigmentation with light green foci was obtained (Fig. 1b); when the thermostat without illumination was used, the callus had loose consistency, dark yellow pigmentation, was hydrated, and disintegrated into separate fragments (Fig. 1c).

The morphometric parameters of aseptic sprouts of plants capable of regenerating after exposure to growth regulators are shown in Table 2.

Shoots of S. truncata plants were microclonal propagated via different types of induced morphogenesis in vitro. A rather active shoots formation in explants in vitro by direct morphogenesis with simultaneous thickening of the base was recorded by us on MS nutrient medium with the addition of $2.0 \mathrm{mg} / 1$ of BA. Intensive mass microclonal propagation of the plants in vitro by activating the growth of available meristems with subsequent obtaining of regenerants was registered on MS medium with the addition of $0.5 \mathrm{mg} / 1$ of BAP and kinetin (multiplication factor $-8.8 \pm 0.6$ per 60 -day cultivation cycle) (Fig. 1f).

The influence of composition of the nutrient medium is statistically significant at the $5 \%$ significance level on the multiplication factor of the explants $\left(F>F_{1}\right.$, $\left.\mathrm{F}=58.18, \mathrm{~F}_{1}=2.62 ; \mathrm{p}<0.05\right)$ and on the sprout length 
Table 2. Growth characteristics of $S$. truncata plant shoots cultivated on modified nutrient media MS, 60 days in vitro culture

\begin{tabular}{|c|c|c|c|c|c|}
\hline Variants & $\begin{array}{l}\text { The composition } \\
\text { of the nutrient medium }\end{array}$ & $\begin{array}{l}\text { The length of one segment } \\
\text { section of sprouts } \\
\text { (mean } \pm \text { standard error), } \mathrm{cm}\end{array}$ & $\begin{array}{c}\text { Plants multiplication } \\
\text { factor } \\
\text { (mean } \pm \text { standard error) }\end{array}$ & Pigmentation & $\begin{array}{l}\text { The presence } \\
\text { of the root } \\
\text { system }\end{array}$ \\
\hline $\mathrm{C}$ & hormones free & $1.0 \pm 0.2$ & $2.0 \pm 0.3$ & light green & + \\
\hline 1 & $2.0 \mathrm{mg} / 1 \mathrm{BA}$ & $0.5 \pm 0.1$ & $10.0 \pm 0.7$ & light green - & - \\
\hline 2 & $\begin{array}{l}0.5 \mathrm{mg} / \mathrm{lBA}+0.5 \mathrm{mg} / \mathrm{l} \\
\text { kinetin }\end{array}$ & $1.2 \pm 0.2$ & $8.8 \pm 0.6$ & green & + \\
\hline 3 & $1.0 \mathrm{mg} / 1 \mathrm{IBA}$ & $1.1 \pm 0.2$ & $1.6 \pm 0.2$ & green & + \\
\hline 4 & $0.25 \mathrm{mg} / 1 \mathrm{kinetin}$ & $1.4 \pm 0.1$ & $3.8 \pm 0.4$ & green & + \\
\hline 5 & $\begin{array}{c}0.25 \mathrm{mg} / \mathrm{l} \text { kinetin }+2 \mathrm{~g} / \mathrm{l} \\
\text { activated carbon adsorbent }\end{array}$ & $1.5 \pm 0.1$ & $4.2 \pm 0.4$ & green & + \\
\hline
\end{tabular}

Notes: $\mathrm{C}$ - control - medium without hormones; the presence of the root system «+»- present; «-»- absent)

$\left(\mathrm{F}>\mathrm{F}_{1}, \mathrm{~F}=5.42, \mathrm{~F}_{1}=2.62, \mathrm{p}<0.05\right)$. All the suggested modified nutrient media induced the development of the root system of formed sprouts, the exception was Variant № 1 (Tab. 2). Thus, in the case of use of $1.0 \mathrm{mg} / 1$ IBA, regeneration of the root system, starting from the periphery of the explants, was registered in more than $90 \%$ of the explants (Fig. 1D, E).

\section{Discussion}

MS nutrient medium is basic, universal, balanced with mineral nutrients, so it is often used as a basis in studies with tissue culture in vitro. In our studies, as well as the authors (Sriskandarajah et al. 2004; AlRamamneh et al. 2006; Deeksha Raj et al. 2020), we used solid nutrient medium prepared according to MS formula for microclonal propagation of $S$. truncata plant explants.

In our studies, intense callus formation on phylloclade explant $S$. truncata fixed on MS medium with addition of BA $(1.0 \mathrm{mg} / \mathrm{l})$ and NAA $(0.3 \mathrm{mg} / \mathrm{l})$, moreover, with the predominance of cytokines over auxin. In studies by other authors (Sriskandarajah and Serek 2004; Al-Ramamneh et al. 2006) also for efficient callus formation in Schlumbergera cultivars used nutrient medium MS with TDZ supplemented with $(5.0 \mathrm{mg} / \mathrm{l})$ and NAA $(0.2 \mathrm{mg} / \mathrm{l})$, with a significant predominance of cytokinin over auxin (almost 25 times). This difference in the ratio of growth regulators, in our opinion, can be explained by the different demands of the tissues of experimental plants.
It is known from the literature review that the intensive microclonal propagation of Schlumbergera plant explants occurs on a nutrient medium with the addition of cytokinins (Kinetin, BA, TDZ, Zeatin) (Perez et al. 1999; Sriskandarajah et al. 2004). In particular, in research by Sriskandarajah et al. (2004) active sprouts formation in cultivars Schlumbergera was observed on MS medium with addition of cytokinins $(6.1 \mathrm{mg} / 1$ BA, $5.9 \mathrm{mg} / 1 \mathrm{TDZ}, 5.9 \mathrm{mg} / \mathrm{l}$ zeatin). According to our research, a rather active sprouts formation in explants $S$. truncata in vitro by direct morphogenesis with simultaneous thickening of the base was recorded by us on MS nutrient medium with the addition of $2.0 \mathrm{mg} / 1$ of BA. According to the research by Deeksha Raj et al. (2020), the optimal nutrient medium for obtaining the largest number of sprouts from the phylloclade explant of $S$. truncata by direct regeneration consists of $3.0 \mathrm{mg} / 1$ of BAP with constant $0.1 \mathrm{mg} / 1 \mathrm{NAA}$. In our opinion, the necessity of using different concentrations of growth regulators, could be peculiar for different genotypes, the season of introduction of plant material and the age of donor plants.

\section{Conclusions}

This experiment shows the natural (genetically determined) ability of Schlumbergera truncata to recover plants from the phylloclade explant of sprouts on a nutrient medium. The natural ability of parts of the shoot in places of injury to actively accumulate callus as a natural mechanism for self-preservation. The type, 
concentration of hormones and lightening regime affect the regeneration intensity of shoots from the callus culture.

\section{References}

Al-Ramamneh, E. et al. 2006. Plant regeneration via somatic embryogenesis in Schlumbergera truncata. Plant Cell, Tissue and Organ Culture, 84 (3), 333-342.

Amir, A. et al. 2001. Callogenesis, embryogenesis and organogenesis in Christmas cactus (Schlumbergera bridgesii). Pakistan Journal of Botany, 33, 569-574.

Butenko, R.G. 1964. Isolated tissue culture and physiology of plant morphogenesis. Science, Moscow.

Chornobrov, O.Yu., Bilous, S.Yu. 2016. Peculiarities of microclonal propagation of Schlumbergera truncata (Haw.) Moran plants. Abstr. Conf. Biotechnology: accomplishments and hopes, Kyiv.

Chornobrov, O. et al. 2019. Peculiarities of morphogenesis of the endangered species of willow (Salix spp.) in vitro. Biologia, 65 (1), 1-8. DOI: doi.org/10.6001/ biologija.v65i1.3986

George, E.F. 1993. Plant propagation by tissue culture. The Technology. Exegetics, Westbury, UK.

Deeksha Raj, N., Sathyanarayana, B.N., Venkatesha Murthy, P., Ramesha, V. 2020. In vitro plant regeneration of thanks giving cactus [Schlumbergera truncata (Haw.) Moran] from sliced segment section for shoot proliferation. International Journal of Current Microbiology and Applied Sciences, 9
(8), 1451-1457. DOI: https://doi.org/10.20546/ijcmas.2020.908.166

Kalinin, F.L. et al. 1980. Methods of tissue culture in plant physiology and biochemistry. Naukova Dumka, Kyiv.

Kushnir, G.P., Sarnatska, V.V. 2005. Microclonal propagation of plants. Naukova Dumka, Kyiv.

Linsmaier, E.M., Skoog, F. 1965. Organic growth factor requirements of tobacco tissue culture. Physiologia Plantarum, 18, 100-127.

Murashige, T., Skoog, F. 1962. Revised medium for rapid growth and bioassays with tobacco tissue cultures. Physiologia Plantarum, 15 (3), 473-497.

Perez, J. et al. 1999. Reproduction in vitro del 'Cactus de Navi-dad' Schlumbergera truncata (Haworth) Moran. Cactaceas y Suculentas Mexicannas, 44 (3), 79-83.

Smith, R.H. 2012. Plant Tissue Culture: Techniques and Experiments, 55.

Sriskandarajah, S. et al. 2007. Biotechnology of Schlumbergera and Rhipsalidopsis. Floriculture and Ornamental Biotechnology, 1 (1), 14-19.

Sriskandarajah, S., Serek, M. 2004. Regeneration from phylloclade explants and callus cultures of Schlumbergera and Rhipsalidopsis. Plant Cell, Tissue and Organ Culture, 78, 75-81.

Staba, J.E. 1969. Plant tissue culture as a technique for the phytochemist. Recent Advances in Phytochemistry, 2, 75-105.

Udalova, R.A. 1980. The family of cactus (Cactaceae). Life of plants (in 6 volumes). Vol. 5, Part 1. Flowering plants (ed. A.L. Takhtagyan). Prosveschenie, Moscow, 353-361. 